高分子論文集 (Kobunshi Ronbunshu), Vol. 46, No. 8, pp. 473-479 (Aug., 1989)

\title{
高分子鎖の直接電子顕微鏡観察
}

\author{
椎橋 透*1 $・$ 広瀨 和正 ${ }^{* 2} \cdot$ 田形信雄*3
}

（受付 1989 年 3 月 3 日・雷查終了 1989 年 5 月 23 日）

\begin{abstract}
要 旨 溶液中で広がっているポリマーをそのままの状態で固定できれば, 分子の大きさと形態, ゲルや橋かけ コムの網目楀造を直接的に透過型電子顕微鏡 (TEM) で钼察することができると考え，ポリイソプレン (IR) 試料 をスチレンモノマーで溶解・膨潤後にスチレンを重合して固定した. 網目鎖平均分子全 $\left(\boldsymbol{M}_{\mathrm{c}}\right)$ が既知の 4 種類の IR 橋加物についてこの方法で調製し OsO4で染色後に TEM 観察した結果， ミク只相分離した網目塆造が钼察され た. 钼察された棝目の単位胞の平均のサイスは，分子量 $\boldsymbol{M}_{\mathrm{c}}$ を有するポリマーの非捸動状態の末端間距離に比較的 よく一致した．TEM写真上の網目部分の長さを多数計测することにより，相対的な網目鎖長の分布曲線を得るこ とが可能であることを示した，IRのソル分子の場合の TEM 像は球形であり，球の直径は IR の分子吾から計算し た非捸動状態の末端間距離に比較的よく一致した。しかし 1 分子を钼察したすのではなく，10 分子程度のIR の旅 集体と結論された.
\end{abstract}

\section{1 楮言}

透過型電子影微鏡 (TEM) の分解能は 1 2Åであり， 1 分子のポリマーを観察するのに十分なすのである。例 えば, 分子量 100 万のポリマーが密度 1 の剛体球として 存在する場合, その直径は約 $150 \AA ̊ 丿$ である. 1 分子のポリ マーを孤立した状態で固定し，適当なコントラストをつ けてやることができれば，容易に観察できる大きさとい えよう。このような考えから，低濃度のポリマー溶液を 支持膜上に噴霧して 1 分子ずつ“剛体球”化した後，金 属蒸着によるシャドゥイングを施した試料を TEM 観察 することによりポリマーの分子量及び分子量分布を測定 した報告がなされているリで).

溶液中のポリマーは“㓮体球”よりあはるかに広がっ ている゙ので，TEM 観察はさらに容易になろう．溶液中 で広がっているポリマーをそのままの状態で固定できれ ば, 分子の大きさと形態, ゲルや橋かけコムの網目構造 を直接的に TEM で観察することができよう。 ポリマー 試料に対して良溶媒である重合性モノマーを用い, 溶解 後にモノマーを重合して固定することを考えた。 ポリ マー試料としては合成シスポリイソプレン (IR)を， モ ノマーとしてはスチレンを選んだ。また OsO4が IR を

*1 日本合成コム(株)リサーチセンター（③05 荻城県つくば 市御幸が丘 25)

* 日本合成ゴム(蛛)開発センター（５５10 三重県四日市市川 尻町 100)

*日本合成コム(株)研究開発部（104 東京都中央区築地 211-24)
よく染色してPS を染色しないことに着目し，TEM 観察 時にコントラストを付与させる目的で用いた.

重合性モノマーで包埋して TEM 観察試料とする方法 は樹脂包埋法(5) 文呼ばれており，主として生体組織の 観察に利用されている. 合成ポリマーの分野において 6，コムブレンド系でのドメインサイズの測定めやフ ロックポリマーのミクロ相分離構造の測定”に利用され た例もある。しかしながらポリマー鎖を直接観察しょう 之試みた例は，これまでにない，本方法により得た天然 ゴム (NR), IR のソル部とゲル部の TEM 写真を前報10) に示したが，TEM像がソルやゲルの分子形態を厳密に 反映したものか否かの確認はまだできていなかった，本 研究では，単分散分子量の IR 及び橋かけ密度が既知の IR 橋かけ物をモデル試料として用い，理論からの予測 との一致性について議論する.

\section{2 実駼}

\section{1 試料}

単分散分子量の IR としては $n$-BuLi を触媒として重 合し, 数平均分子量 $\left(\bar{M}_{n}\right)$ か $5 \times 10^{4}, 3.1 \times 10^{5}, 5.3 \times 10^{5}$ の 3 種類を得て用いた. IR 橋かけ試料としては, 過酸化シ クミルの量を変えてシェル社製 CARIFLEX IR309を $160^{\circ} \mathrm{C}, 40$ 分純ゴム橋かけし，橋かけ密度の異なる 4 種 類を得て用いた (Table 1). 網目鎖平均分子量 $\left(M_{c}\right)$ は, トルエン中での平衡膨潤度から Flory-Rehner の式(1)を 用いて得た。

\section{2 四子影微鏡測定}

単分散分子量の IR 試料については $0.0074 \sim 0.62 \%$ の 
濃度でスチレンモノマーに溶解させた．IR 橋かけ試料 については $0.2 \mathrm{~cm} \times 0.2 \mathrm{~cm} \times 2 \mathrm{~cm}$ の大きさの試料片を 十分な量のスチレンモノマーで平衡膨潤させた。これら のスチレン溶液あるいは膨潤液に過酸化ベンゾイルをス チレンに対し $1 \%$ 加え, 電子顕微鏡用ゼラチンカプセル 中で $70^{\circ} \mathrm{C}, 15$ 時間スチレンを重合・固化した，四酸化才 スミウム $\left(\mathrm{OsO}_{4}\right)$ でゴム鎖を染色・固定した後，LKB 社 の超ミクロトームで 500〜1000Å の厚さの超薄切片を作 製した. TEM 観察には, フィリップス社製 EM-400 型透 過型電子顕微鏡を用いた．前報(1)における超薄切片作製 後に $\mathrm{OsO}_{4}$ で染色するという手順では，超ミクロトーム のナイフでゴム鎖が圧縮されてへん平な形状に变形する ことが判明したので，上記のように OsO 4 染色後に超薄 切片を作製する手順を採用した。

Table 1. Characterization of cured rubber

\begin{tabular}{cccc}
\hline \hline $\begin{array}{c}\text { Amount of } \\
\text { DICUP) }\end{array}$ & $Q_{\mathrm{TL}}{ }^{\mathrm{b})}$ & $M_{\mathrm{c}} \times 10^{-3 \mathrm{c})}$ & $Q_{\mathrm{ST}}{ }^{\mathrm{d})}$ \\
\hline $0.1 \%$ & 12.0 & 43 & 9.5 \\
0.3 & 8.2 & 18 & 6.7 \\
1.0 & 5.8 & 9 & 4.8 \\
2.0 & 4.7 & 5.5 & 3.9 \\
\hline
\end{tabular}

D) Dicumyl peroxide.

b) Swelling ratio in toluene.

${ }^{c)}$ Molecular weight between crosslinking obtained from $Q_{\mathrm{TR}}$

d) Swelling ratio in styrene.

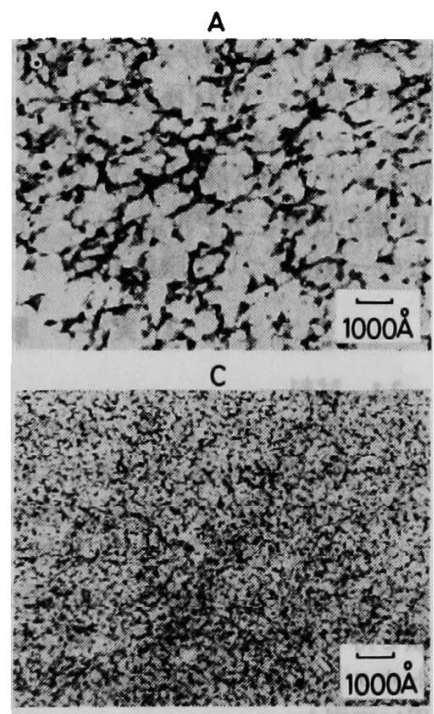

\section{3 結果と考察}

\subsection{IR 橋かけ試料の TEM 観察}

橋かけ密度の異なる 4 試料についての TEM 写真を Fig. 1 に示すが，黒い部分が OsO4で染色された IR 銷 で，白い部分がポリスチレン (PS) である. 4 枚の写真と も黒い部分は網目状にみえるが， $M_{c}$ の小さいものほど 黒い部分はより細く，より密な網目になっている，本方 法における TEM 観察用試料の調製方法は Sperling

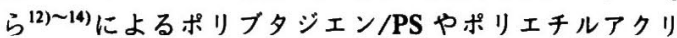
レート/PS 系などの IPN (Interpenetrating Polymer Networks) の製造方法と類似であり, TEM 写真も類似なも のを与える. 本方法においてもスチレンの重合の過程で IR と PS との間で相分離が起こっているものと思われ るが，そのようすは彼らのIPN の場合と少し異なる，す なわち IR はIPNにおける “cell wall” とは成らず，線状 の網目を形成する. Fig. 1 の黒い網目状部分が一部とぎ れているのは“線状”であることを意味している. 超薄 切片の厚さを意識的に薄くするとさらにとぎれることよ り,この解釈が正しいことを確認した．さらに，IR 相の 中には明瞭な PSドメインは存在せず，この点も IPN の 場合と異なる。

彼らの場合との差の原因については明確ではないが, 本方法の場合においては, $\mathrm{OsO}_{4}$ で染色する前に超薄切 片を作製すると IR が変形してしまうことからスチレン の重合は完全には終了しておらず，IR 鎖が PS と残留ス チレンモノマーにより膨潤された状態で固定されている

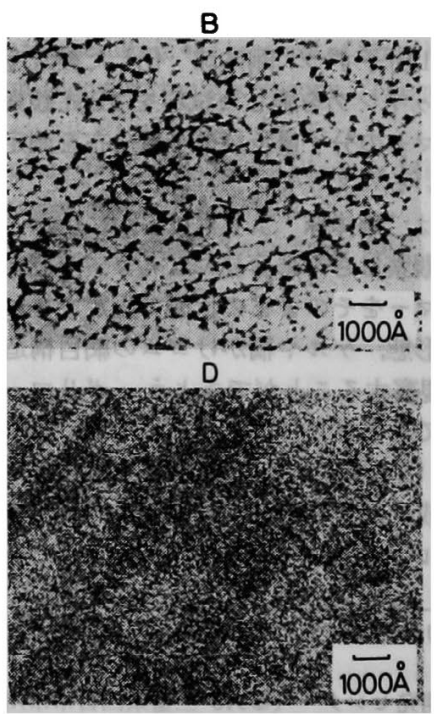

Fig. 1. Electron micrographs of cured rubbers with various molecular weight between crosslinking. Molecular weight between crosslinking $\left(M_{c}\right)$ : (A) $43 \times 10^{3}$; (B) $18 \times 10^{3}$; (C) $9 \times 10^{3}$; (D) $5.5 \times 10^{3}$. 

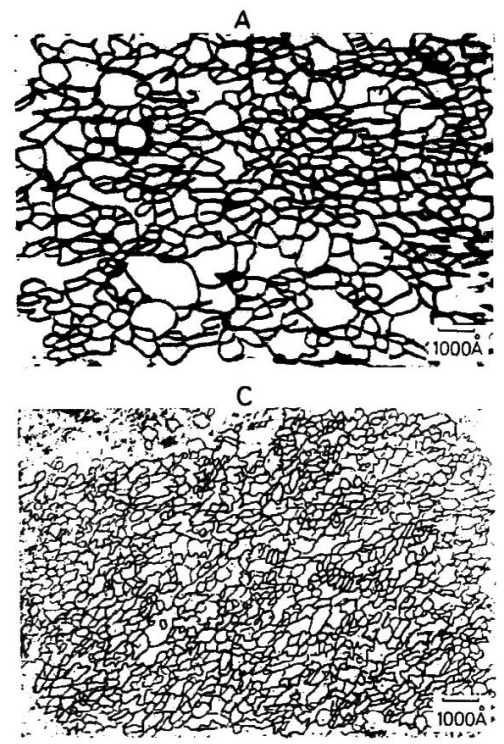

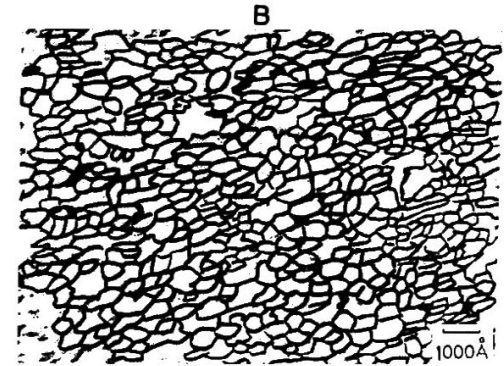

D

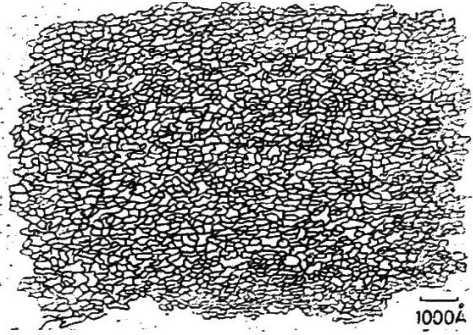

Fig. 2. Schematic network structure of cured rubbers traced from the electron micrographs (Fig. 1). Molecular weight between crosslinking $\left(M_{c}\right)$ : (A) $43 \times 10^{3}$; (B) $18 \times 10^{3}$; (C) $9 \times 10^{3}$; (D) $5.5 \times 10^{3}$.

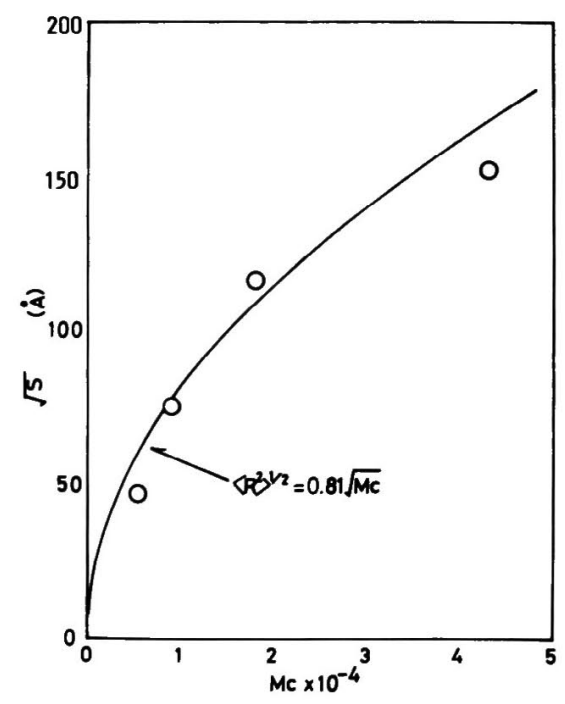

Fig. 3. Relation between the mean square areas of the bright portions on Fig. 2 and $\boldsymbol{M}_{\mathrm{c}}$.

可能性がある.したがって本方法においては上述の IRN の場合に比べて相分離の程度は低く，スチレンモノマー に膨潤された状態での橋かけゴムの網目の形態をより忠 実に保持しているあの之期待される，スチレンの重合前 後で橋かけ試料のマクロな寸法变化は認められないの で, 個々の網目も本来の網目構造を保っている可能性は 大いにある.
網目状の黒い部分が本当に橋かけゴムの網目をとらえ たあのであるか否かを判定するために，ラフにではある が, 写真の網目の大きさを理論的に予測される大きさと 比較した。 この際, Fig. 1 の写真を直接計測するのが困 難であったため，黒い部分を黒インクでなぞりコントラ ストをより鮮明にした (Fig. 2) 後, ルーゼックス 450 粒 子アナライザーで計測した。

黒い網目で囲まれた 1 個の白い部分の平均の面積 $(S)$ を求め, その平方根 $\left(S^{1 / 2}\right)$ と試料の $M_{\mathrm{c}}$ との関係をプ ロットした結果を Fig. 3 に示すが, $M_{c}$ が大きくなるに つれて $S^{1 / 2}$ の值む大きくなっている. $S^{1 / 2}$ は近似的に写 真の網目の平均長さに相当するはずである. 図中の実線 は, 分子量 $\boldsymbol{M}_{\mathrm{c}}$ を有するポリマーの末端間距離を以下の 式を用いて計算したものである.

$$
\left\langle R^{2}\right\rangle^{1 / 2}=0.81\left(M_{c}\right)^{1 / 2}
$$

式 (1) は, 倉田と Stockmayer ${ }^{15)}$ が Flory-Fox の式 ${ }^{(6)}$ を用 いてシスポリイソプレンに対して得た非摂動状態の末端 間距離と分子量の関係である.このようにして見積もっ た末端間距離と $S^{1 / 2}$ とは比較的よく一致している. 網目 鎖間の距離は両末端が拘束されていない場合のポリマー の末端間距離とは同じでないであろうし17)，また排除体 積効果をどのように取り入れるべきかは現時点では明ら かではない.したがって Fig. 3 の示す一致性から厳密な 議論はできないが, 本方法でとらえた写真が橋かけゴム の網目の大きさあるいはそれに比例した大きさを忠実に 反映したものと結論される.

Fig. 2 の白い部分の直径 $(L)$ を目盛りつきのルーペで 
計測して得た分布曲線を Fig. 4 に示す．本方法により網 目の大きさの分布, すなわち網目鎖長の分布も知ること ができる. ただし，本方法で得られる TEM 像は超薄切 片の厚みによる網目鎖の重なりの影響を受けている，厳 密には超薄切片の厚みを計測し， 3 次元的に画像解析す ることにより“重なり”を補正する必要があるわけであ るが,この点については未解決である. しかしながら超 薄切片の厚みを実験的に可能な限りそろえて Fig. 4 のよ うな分布曲線を得ることにより，橋かけコム同士の相対 的な網目銷分布の比較は十分可能であろう.

3.2 ポリマー1 分子の TEM 観察の試み

本方法でゾル分子を観察した場合の像が 1 分子ずつを とらえたものであるか否かを判定するために, 分子量の 異なる 3 種類の IR を用い，TEM 像の大きさと分子量と の対応を調べた. 希薄溶液中のポリマーは 1 分子ずつ孤

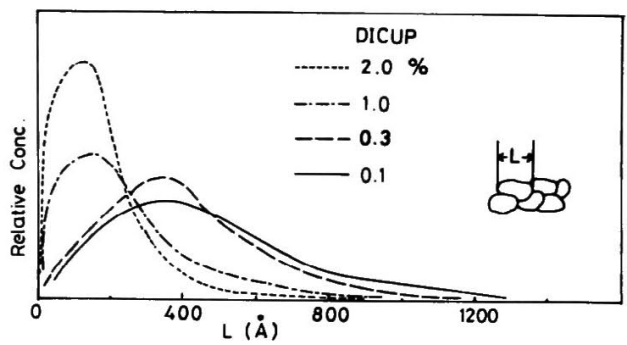

Fig. 4. Crosslinking density distribution curves calculated on the basis of Fig. 2.

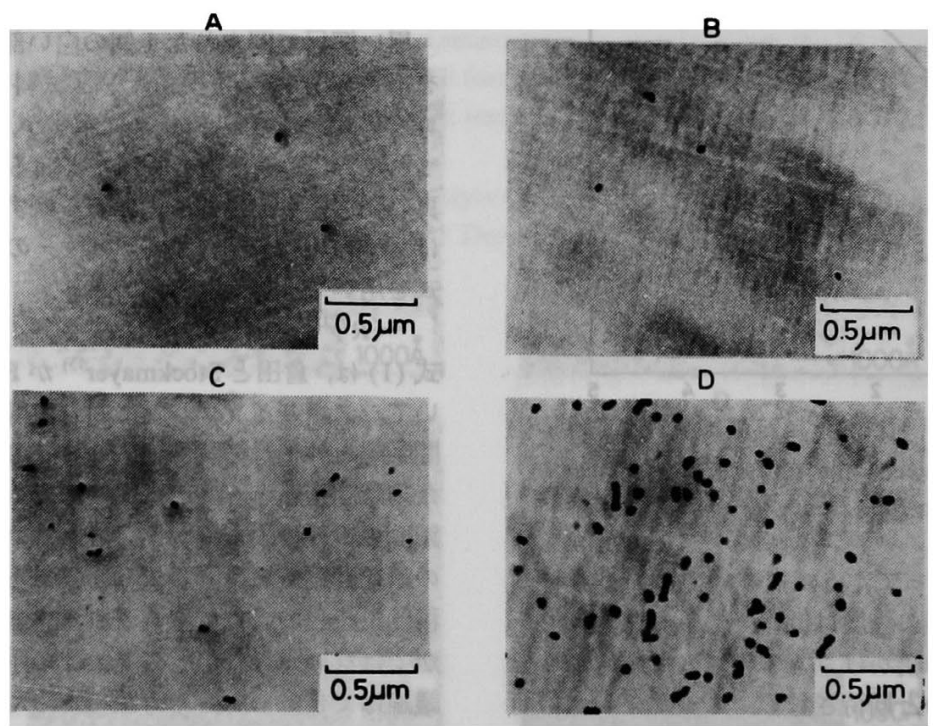

Fig. 5. Electron micrographs of IR with $\bar{M}_{n}$ of $3.1 \times 10^{5}$. Concentration: (A) $0.0074 \%$; (B) $0.012 \%$; (C) $0.11 \%$; (D) $0.61 \%$.
立しているはずなので，孤立したままスチレンが重合・ 固化すればポリマー1 分子の TEM 観察が可能となる. スチレンの重合中に IR 分子同士が凝集することを防ぐ ためには，IR の濃度を極めて希薄にすべきだと考え， TEM 像に対する IR の濃度の影響を調べた. $\bar{M}_{n}$ が $3.1 \times$ $10^{5}$ の IRについて $0.61 \%, 0.11 \%, 0.012 \%, 0.0074 \%$ の濃 度で得た TEM 写真を Fig. 5 に示す. 写真の粒子の直径 は小さいあので $200 \AA ̊ 丿$, 大きいもので $500 \AA ̊$ 程度であり, 粒子の大きさと形に対する濃度依存性は大きくはない が, 高濃度では明らかに疑集していると判定されるもの あ存在する. 高倍率で得た写真の例を Fig. 6 に示すが, 写真 A では直径 $350 \AA$ の球形の 1 粒子と判定されるも のの, 写真 Bでは 3 個の粒子が凝集あるいは重なってい るものと判定される. 写真 B の例のように明らかに疑集 あるいは重なっていると判定されるすのを除いて各粒子 の直径を計測し, 分子量の値から理論的に予測される大 きさと比較した.

数平均粒子径を試料の $\bar{M}_{n}$ に対してプロットした結果 を Fig. 7 に示す. $\bar{M}_{n}$ が $5 \times 10^{4}$ の IR の粒子径はポリ マー濃度依存性が大きく，高濃度では IR 分子同士の凝 集が顕著に起こっていることを示している. しかし $0.01 \%$ 以下では，粒子径はほぼ一定となっている．これ に対して分子量の大きい $\bar{M}_{n}$ が $3.1 \times 10^{5}$ の IR では, 濃 度依存性は小さい, 分子量の小さいものほど拡散係数が 大きいのでスチレンの重合中に IR 分子同士の衝乫がよ り頻繁に起こり,このため凝集が起こっているものと推 察される. 図中の実線は前述の倉田らによる非摂動状態 

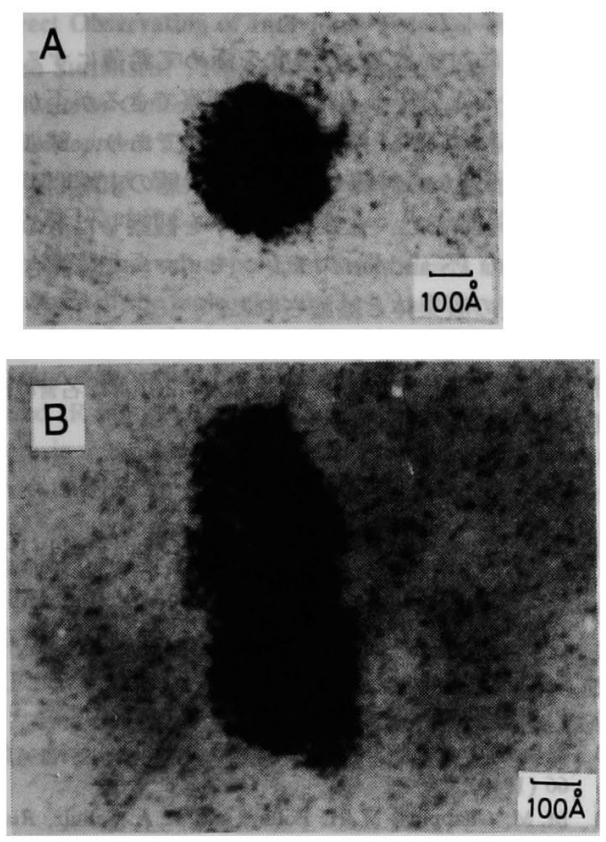

Fig. 6. High magnification electron micrographs of IR with $\bar{M}_{n}$ of $3.1 \times 10^{5}$. Concentration: (A) $0.0074 \%$; (B) $0.61 \%$.

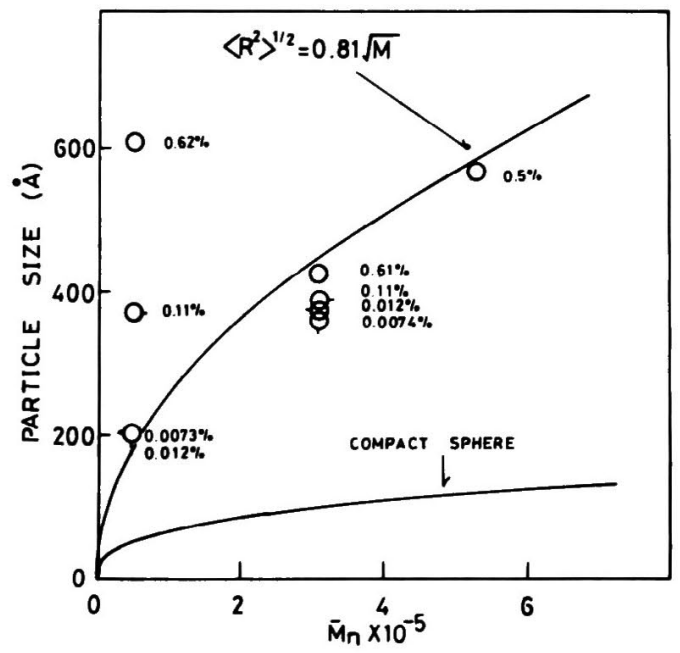

Fig. 7. Relation between the particle sizes and $\bar{M}_{n}$ of IR samples polymerized with $\mathrm{Li}$ catalyst.

の末端間距離と分子量の関係であり, 下の実線は密度 1 の剛体球を考えた場合の球の直径と分子量の関係であ る. 低濃度で調製した試料の写真より得た粒子径は剛体 球の直径よりもはるかに大きく，Flory-Fox の式から見 積もった末端間距離と比較的よく一致している. 本方法

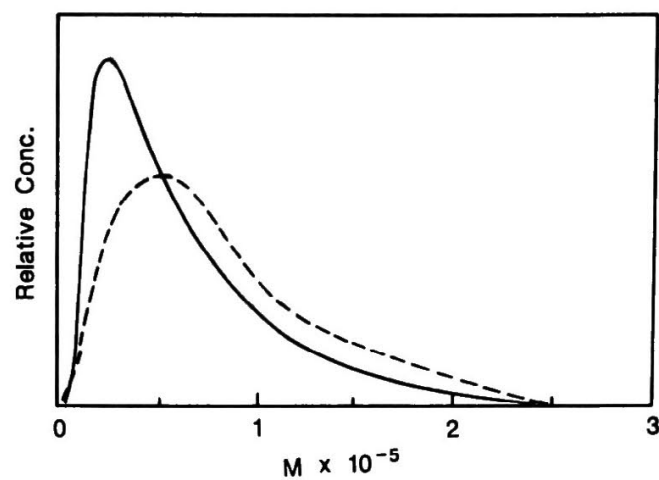

Fig. 8. Molecular weight distribution curves of IR with $\bar{M}_{n}$ of $5.3 \times 10^{5}$. method.

でスチレンを重合した場合に，溶解していた IR 分子が どのような大きさ, 形態で固定されていくべきかという 理論的な予測は容易ではなく，現時点ではできていな い. それゆえ試料 IR の分子量値から見積った末端間距 離に一致することや球形であることに特別の意義はな い.

ここではわずかな実験事実に基づき，スチレンの重合 中に起こっている現象をラフに推察してみる. 濃度的に は大きく異なるものの耐衝撃性 PS (HIPS) の製造方法 に類似であるので, IR 鎖への PS のグラフトが起こって いるであろう. スチレンの重合の進行に伴い, IR と溶媒 系 (PS十スチレン) とは非相溶状態へ移っていくと推定 されるが,この際 IR 鎖にグラフトした PS 鎖が界面活 性剤の役割を果たして IR 分子同士の凝集を防げている 可能性がある. 同時に溶媒系の粘度の上昇により IR 分 子の並進運動性は低下し, やがて固定される. $70^{\circ} \mathrm{C} に て ~$ 15 時間スチレンを重合することによりマクロ的には十 分硬いPS となるが，5〜6時間の重合ではマク口的に判 定しても柔らかいPSしかできないことから，この系に おける重合速度は早いものではない。この間 IR 分子の 形はエントロピー的により安定な球形になると考えられ る. 前述のとおり, IR 鎖中にスチレンモノマーが残留し た状態で反応を止めていると推定されるので, 剛体球状 の場合に比べてよりふくらんだ状態で固定されていよ う.このような解釈にたてば，分子を観測している可能 性は十分ある.

TEM で得られる粒子の大きさが試料 IR の分子量と 相関があることを利用して, 粒子の大きさの分布から分 子量分布を算出し, GPC 曲線から得た分子量分布曲線 と比較を行った. 粒子の大きさから分子量への換算は,

Fig. 7 に示した末端間距離と分子量の関係式を用いた. 100 個の粒子について粒径を計測して頻度分布曲線を得 た. GPC 曲線は 15 分割し $[\eta] M$ と溶出量の関係（汎用 
较正曲線）から常法 ${ }^{(8)}$ により分子量分布曲線を得た。 一 例として， $\bar{M}_{n}$ が $5.3 \times 10^{5}$ の IR について TEM 法と GPC 法とで得た結果を Fig. 8 に示す. TEM 法で得た分 布曲線は GPC 法の曲線に比べて，（i）全体的に低分子 量側に寄っていること, (ii) 高分子量側の裾が大きいこ との 2 点が大きく異なる. (i) の原因としては, TEM 像 の粒径から分子量への換算として用いた Fig. 7 の関係式 が実験点よりも上側であるために分子量を過小評価して いることが考えられる. (ii) の原因としては，擬集によ る肥大粒子が高分子量側の裾として寄与しているすの之 推察される. 擬集の有無を判定する上で Fig. 7 のような 平均量での対応だけではなく，サイズの分布を調べるこ とが重要と言える.

1 分子というよりは分子の擬集体を観察している可能 性が高いことが明らかとなったので, 何分子くらいの擬 集体かを調べることにした. 分子の擬集の少ない $0.007 \%$ の濃度で得られた $\bar{M}_{n}$ が $5 \times 10^{4}$ 及び $3.1 \times 10^{5}$ の IR について各 20 枚の TEM 写真につき粒子の数を計数 し、調製搌度から期待される分子の数と比較した. いず れの試料も粒子数は分子の数のおよそ $1 / 10$ であり, 計 算上 10 分子の凝集体之見積られる. TEM 写真の黒い粒 子部分のコントラストが-ー様であることから 10 分子は 一様にPSで膨潤しているすのと判定され，その大きさ は分子が密につまった剛体球を取るときの直径の約 2 倍 である.

ここで述べた方法で観測されるIR は多量の PS and/ or スチレンモノマーで膨潤された 10 分子程度の擬集体 であり，1 分子ではないと結論される. 本検討ではスチ レンの重合速度を最適化する検討は実施していないが, IR 分子の擬集とスチレンの重合とは競争の関係にあろ うから, 㢸集の速度より重合の速度を早くしてやれば 1 分子ごとに孤立させて固定することが可能かもしれな い.この点については今後の課題としたい.

\section{4 結䜽}

$M_{\mathrm{c}}$ が既知の 4 種類の IR 橋かけ物をモデル試料とし て用い, スチレン樹脂包埋法で調製した試料について TEM 観察することにより，橋かけゴムの網目が観察で きる可能性を示した. 钼察された平均の網目の長さは, 分子量 $\boldsymbol{M}_{\boldsymbol{c}}$ を有するポリマーの非摄動状態の末端間距離 に比較的よく一致した. さらに，TEM 写真上の網目部 分の長さをルーペで多数の箇所を計測することにより， 相対的な網目鎖長の分布曲線を得ることが可能であるこ
とを明らかにした.

スチレンに対するIR の漲度を極めて希薄にすること により，IRを1 分子ごとに TEM 観察できるか否かを調 ベた. 得られた TEM 像の形状は球形であり, 球の直径 はIRの分子量から計算した非捸動状態の末端間距離に 比較的よく一致した。 しかし 1 分子を観察したものでは なく，多量の PS and/or スチレンモノマーで膨閣された 10 分子程度の凝集体と結論された。

时辞有益な御討論を頂いた京都大学古川㲚二名誉教授、 東京工業大学井上 隆助教授に感謝致します.

\section{文献}

1) E. Husemann and H. Ruska, J. Prakt. Chem., 156, 1 (1940); Naturwissenschaften, 28, 534 (1940).

2) M. J. Richardson, J. Polym. Sci., C. 3, 21 (1963).

3) G. Koszterszitz and G. V. Schulz, Makromol. Chem., 178, 2437 (1977).

4) P. J. Flory, J. Chem. Phys, 17, 303 (1949).

5) S. B. Newman, E. Borysko, and M. Swerdlow, Science, 110, 66 (1949).

6) M. M. Chappius, M. H. Polley, and R. A. Schulz, Rubber World, 130, 507 (1954); Rubber Chem. Technol., 28, 253 (1955).

7) 小倉光夫, 品川嘉也, J. Electronmicroscopy, 9, 40 (1960).

8) W. M. Hess, C. E. Scott, and J. E. Callan, Rubber Chem. Technol., 40, 371 (1967).

9) K. Arai, C. Ueda-Mashima, and T. Kotaka, Polymer, 25, 230 (1984).

10）椎插 透, 広瀬和正, 田形信雄, 高分子論文集、46, 467 (1989).

11) P. J. Flory and J. Rehner, Jr., J. Chem. Phys., 11, 521 (1943).

12) A. J. Curtius, M. J. Covitch, D. A. Thomas, and L. H. Sperling, Polym. Eng. Sci., 12, 101 (1972).

13) V. Huelck, D. A. Thomas, and L. H. Sperling, Macromolecules, 5, 340 (1972).

14) L. H. Sperling, J. Polym. Sci., Macromol. Rev., 12, 141 (1977).

15) M. Kurata and W. H. Stockmayer, Fortschr. Hochpolymer Forsh., 3, 196 (1963).

16) P. J. Flory and T. G. Fox, J. Am. Chem. Soc., 73, 1904 (1951).

17）村棉俊介, 谷 久也, “高分子化学”，共立出版，東京 (1974), p. 279.

18）武内次夫, 森 定雄, “ゲルパーミエーションクロマトク ラフィー”, 丸善, 東京 (1976), p. 104. 


\section{高分子鎖の直接電子顕微鏡観察}

\section{Direct Observation of Individual Polymer Molecules by Electron Microscopy}

Toru Shirbashi*1, Kazumasa Hirose*2, and Nobuo TAgata*3

*1 Research Center, Japan Synthetic Rubber Co., Ltd. (25, Miyukigaoka, Tsukuba, Ibaraki, 305 Japan)

*2 Development Center, Japan Synthetic Rubber Co., Ltd. (100, Kawajiri-cho, Yokkaichi, Mie, 510 Japan)

${ }^{*}$ Research \& Development Department, Japan Synthetic Rubber Co., Ltd.

(11-24, Tsukiji 2-chome, Chuo-ku, Tokyo, 104 Japan)

If the individual polymer molecules in a solution could be fixed unchanged just as they are, we could directly see the structure of the molecules, the gels and the networks of the cured rubber by transmission electron microscopy (TEM). Samples of synthetic isoprene rubber (IR) were dissolved or swelled in styrene monomer; then the polymerization of styrene was carried out. Using samples stained with osmium tetraoxide, TEM observations were done. TEM image of cured IR samples showed a network structure. The mean size of the unit cell of the networks in electron micrographs were in relatively good agreement with the unperturbed mean square end-to-end distances of IR segment between cross-link junctures. From the size distribution curves, we can get the relative crosslinking density distribution curves. TEM image of IR sol samples showed spherical particles. The mean diameter of the particles were in relatively good agreement with the unperturbed mean square end-to-end distances of IR molecules estimated from molecular weight. It is concluded that the TEM image was not of the individual polymer molecules, but of aggregates which contained about 10 IR molecules.

KEY WORDS Electron Microscopy / Individual Molecule / Polyisoprene / Network Structure /

End-to-End Distance / Crosslinking Density / Crosslinking Density Distribution /

(Received March 3, 1989: Accepted May 23, 1989)

[Kobunshi Ronbunshu, 46(8), 473-479 (1989)] 